\title{
Res Judicata and Collateral Estoppel Beneath the Corporate Veil $\dagger$
}

Perhaps the most fundamental concept in the law of corporations is that a corporation is a legal entity distmct from its owners. ${ }^{1}$ As such, the corporation is responsible for debts and obligations incurred by it, shielding even a sole-owner stockholder from individual liability. ${ }^{2}$ The protection provided by incorporation, however, is not ironclad. When the owner of a corporation abuses the corporate privilege, the courts are willing to "pierce the corporate veil" to find that the corporation is the mere "alter ego" of the owner and to hold the owner personally hable for the corporate obhigation. ${ }^{3}$ Courts also hold a stockholder individually liable for a corporate debt when the corporation is undercapitalized ${ }^{4}$ and the stockholder actively participated in

$\dagger$ This Comment is a sequel to Comment, Res Judicata and Collateral Estoppel in the Law of Partnership, 65 CALIF. L. REv. 863 (1977).

1. E.g., United States v. Milwaukee Refrigerator Transit Co., 142 F. 247, 253 (E.D. Wis. 1905); H. HENN, HANDBOOK OF THE LAW OF CoRporations aNd OTHER BUSINESS ENTERPRises $\S 78$ (2d ed. 1970) [hereinafter cited as HenN]; N. Lattin, The LaW of Corporations $\$ 11$ (2d ed. 1971) [hereinafter cited as LATTIN].

2. E.g., Hollywood Cleaning \& Pressing Co. v. Hollywood Laundry Serv., Inc., 217 Cal. 124, 17 P.2d 709 (1932); HENN, supra note 1, § 79; LATTIN, supra note 1, § 15; Fuller, The Incorporated Individual: A Study of the One-Man Company, 51 HARv. L. Rev. 1373, 1377 (1938).

3. Under the classic California formulation of the alter-ego doctrime, the acts and obligations of a corporation will be recognized as those of a particular person when

the corporation is not only influenced and governed by that person, but . . . there is such a unity of interest and ownership that the individuality, or separateness, of said person and corporation has ceased, [and when] the facts are such that an adherence to the fiction of the separate existence of the corporation would, under the particular circumstances, sanction a fraud or promote injustice.

Minifie v. Rowley, 187 Cal. 481, 487, 202 P. 673, 676 (1921). See also United States v. Milwaukee Refrigerator Transit Co., 142 F. 247, 255 (E.D. Wis. 1905); HeNN, supra note 1, § 146 \& n.2 (list of various inetaphors used to describe the theory); LATTIN, supra note 1 , 14.

In most cases the plaimtiff is attempting to pierce the veil to reach an individual owner of the corporation. See generally Fuller, supra note 2, at 1376-84. But the same considerations apply whether a single individual or a group of individuals has assumed an identity with the corporation, see HENN, supra note 1, § 147; or when another corporation has a unity of interest and ownership with a subsidiary corporation, e.g., Mirabito v. San Francisco Dairy Co., 3 Cal. App. 2d 54, 47 P.2d 530 (1st Dist. 1935). See HeNn, supra note 1, § 148; LatTIN, supra note 1, § 24 . In the interest of simplicity, the term "owner" will be used to denote "owner or owners" except in those places where it is clear that only the singular or plural is imtended.

4. E.g., Minton v. Cavaney, 56 Cal. 2d 576, 364 P.2d 473, 15 Cal. Rptr. 641 (1961); Automotriz del Golfo de Cal. S.A. de C.V. v. Resmick, 47 Cal. 2d 792, 306 P.2d 1 (1957). Undercapitalization has been viewed both as a variant of piercing theory, e.g., LATTiN, supra note 1, § 15, and as a separate, corollary doctrime, e.g., Schifferman, The Alter Ego Doctrine in California, in Advising CALIfornia Business Enterprises 785, 796 (Cont. Ed. Bar 1963). Often an under- 


\section{the conduct of corporate affairs. ${ }^{5}$}

Occasionally, injustice may result from the doctrine of limited liability after a creditor obtams a judgment against a corporation. On attempting to enforce the judgment, the creditor may find that the corporation is insolvent or has gone into bankruptcy, ${ }^{6}$ or that it never had

capitalization theory is used to satisfy the fraud or injustice requirement of the alter-ego test. See note 3 supra and note 6 infra. It can be argued that the court in Minton was using the alter-ego test but was elevating the injustice (i.e., undercapitalization) component and mimimizing the showing required for unity of interest and ownership. Whether the undercapitalization approach is viewed as a separate test or inerely the same test with a different emphasis does not affect the analysis of this Comment. The Comment will use the term "alter ego" only when a showing of dommation of the corporation by the owner/stockholder has justified piercing the veil. It will use the term "undercapitalization" when little or no showing of domination has been made and the court has, nevertheless, pierced the corporate veil.

Courts have sometines pierced the veil under circumstances other than unity of interest and ownership (alter-ego pierce) or initial undercapitahzation, as in cases when the corporate form has been used to circumvent a statute, e.g., United States v. Milwaukee Refrigerator Transit Co., 142 F. 247 (E.D. Wis. 1905) (Elkins Act, unlawful rebates). This Comment is concerned with crcditors' suits and will not discuss these other types of cases since they rarely fit the two-suit hypothesis considered here. In these other types of cases, piercing the veil will necessarily be undertaken in the first suit because the cause of action itself arises partially as a result of the abuse of the corporate form. See also LATTIN, supra note 1, §§ 15-18. This Comment also will not discuss sccond contempt suits brought against directors or officers when their corporation has been enjoined from infringing a patent or copyright in a previous suit. See note 21 infra.

5. For clarity, this Comment uses the term "stockholder" to refer to the object of an undercapitalization attack and the term "owner" to refer to the object of an alter-ego pierce, even though an alter-ego owner may own stock in the corporation. Failure to issue stock is, however, one factor that inay be considered in piercing the veil under an alter-ego theory. See Associatcd Vendors, Inc. v. Oakland Meat Co., 210 Cal. App. 2d 825, 838-40, 26 Cal. Rptr. 806, 813-15 (1st Dist. 1962). It is not clear from the cases whether a person can be held personally liable as a participating director in the absence of an ownership interest in the corporation. In Minton v. Cavaney, 56 Cal. 2d 576, 364 P.2d 473, 15 Cal. Rptr. 641 (1961), for instance, Cavaney was probably an equitable owner in addition to holding offices as seeretary, treasurer, and director of the corporation. The theory behind the undercapitalization pierce is that it is unfair to use the corporate form without providing initial capital in reasonable proportion to the habilities the corporation is likely to incur. It can be argued that a director who has no interest in the corporation is getting no benefit froin the undercapitalization, and therefore should not be held liable when the veiI is pierced.

Walkovszky v. Carlton, 18 N.Y.2d 414, 223 N.E.2d 6 (N.Y. 1966) suggests a variant of the undercapitalization theory that inight be labelled the "aggregation theory." An individual or corporation might own several small corporations that are actually part of a larger business enterprise (Carlton was alleged to be a stockholder in 10 corporations each of which owned two taxicabs). If each individual corporation is undercapitalized, the court might consider the business in the aggregate and hold each corporation responsible for the debts and obligations of the others. Although this approach is not part of classical piercing theory, nevertheless, it provides another example of an atteinpt to impose liability for the corporate obligation beyond the corporate entity. The hypothetical circumstances of joint operation sufficiently parallel the usual undercapitalization problein to allow the same considerations discussed throughout the Comment to apply to both theories.

6. E.g., Motores de Mexicali, S.A. v. Superior Court, 51 Cal. 2d 172, 331 P.2d 1 (1958). This situation will almost always be the reason the plaimtiff has brought the second suit. Care unust be taken to distinguish between insolvency at the time of enforcement, which may be used as a factor to justify an "alter-ego" finding, and lack of initial capitahization, which alone may support a pierce under the "undercapitalization" theory. See text accoinpanying notes 4-5 supra. For a discussion of other factors courts have considered in piercing the veil, see Associated Ven- 
any assets. ${ }^{7}$ The judgment creditor may, therefore, want to bring a second suit against the owner of the corporation, using a piercing theory to attempt to hold him individually liable for the corporate debt. Because this second suit rests upon the same cause of action as the initial suit against the corporation and will involve issues that were litigated in the first suit, the creditor must confront the doctrines of res judicata and collateral estoppel. ${ }^{8}$

This Cominent examines the effects of res judicata and collateral estoppel on the riglits of a plaintiff to bring a lawsuit against the owner or stockholder of a corporation after suit has already been brought and liability established against the corporation itself. Part I surveys the

dors, Inc. v. Oakland Meat Co., 210 Cal. App. 2d 825, 838-40, 26 Cal. Rptr. 806, 813-15 (1st Dist. 1962). Examples of such factors are commingling of personal and corporate funds, the treatment by an individual of the assets of the corporation as her own, and the holding out by an individual that she is personally liable for the debts of the corporation.

7. E.g., Minton v. Cavaney, 56 Cal. 2d 576, 364 P.2d 473, 15 Cal. Rptr. 641 (1961).

8. This Coinment uses the term res judicata to apply only to inerger, or "claim preclusion," unless the sentence indicates that the term is used in its broader sense, as in the discussions of public policy. When used in its teclunical sense, res judicata dictates that if a plaintiff wims a suit on the merits, all clains against the same defendants and their privies arising out of the same cause of action are "merged" in the judgment; the plaintiff cannot bring a second suit against them. Collateral estoppel will be used to refer to the more limited "issue preclusion"; collateral estoppel renders a prior judgment on the merits conclusive as to issues actually litigated and deterInined between the same parties, or those in privity with them, although the cause of action in the second suit may be different. See, e.g., IB Moore's Federal Practice fo 0.405 [3] (2d ed. 1974) [hereinafter cited as MOORE].

The Comment will not discuss the law of "bar," also a type of res judicata. Traditionally, if the plaintiff lost the first suit, res judicata barred him froin inaintaining a second suit against the same defendants and their privies on the same cause of action. Id. Modern theory, however, has allowed defendants who were not parties or privies to the first suit to assert a defensive bar against a plaintiff who has already had a fair chance to litigate an issue in a previous suit. E.g., BlonderTongue Laboratories, Inc. v. University of Illinois Fndtn., 402 U.S. 313, 320 (1971); Bernhard v. Bank of America, 19 Cal. 2d 807, 122 P.2d 892 (1942); RESTATEMENT (SECOND) OF JudGMENTS, Explanatory Notes app. $\$ 88$ (Tent. Draft No. 3, 1976). If the plaintiff loses in his suit to establish corporate liability, he will bring a second suit against the owner only as an individual, not on a piercing theory, to hold the owner liable for the corporate obligation. Cf. Comment, Res Judicata and Collateral Estoppel in the Law of Partnership, 65 CALIF. L. REv. 863, 872-75 (1977) (bar in the partnership context) [liereinafter cited as Partnership Res Judicata]. The court's analysis of whether the plaintiff ought to be barred will center on whether issues necessary to the plaintiffs claim were litigated in the first suit; the court will not need to examine the relationship between the corporation and the owner. Compare Ballis v. Latta, 102 Pa. Super. Ct. 66, 156 A. 596 (Super. Ct. 1931) (suit brought on promissory notes against president of corporation; defense of lack of performance of underlymg contract already litigated in first suit against corporation is res judicata and bars second suit) with McAlevy v. Litch, 234 Mass. 440, 125 N.E. 606 (Mass. 1920) (general verdict does not indicate wliether plaintiff lost first suit against corporation on issue of whether owner was acting within the scope of his einployment; second suit against owner as an individual not barred).

Interestingly, the defendant has also been bound in a second suit by a defense used to defeat the plaintiff's clain in the first suit against the corporation, in the nature of an estoppel in pais. Horn v. Bennett, 253 App. Div. 630, 3 N.Y.S.2d 525 (App. Div. 1938) (plaintiff loses first suit against corporation on defense of lack of authority of contracting officer/owners; owners are estopped from claiming they were in fact authorized in second suit against them as individuals, since they benefited from clann in the first suit). 
law of res judicata, which dictates whether suit may be brought at all. Part II discusses the law of collateral estoppel, which dictates whether any of the issues litigated in the first suit can be considered determined for purposes of the second. The Comment argues that most courts have taken an unnecessarily restrictive view of issue preclusion due to a failure to examine critically the theory behind piercing the veil and to connect that theory to the collateral estoppel inquiry. This Coinment, therefore, proposes that the courts adopt a different approach, already adopted by a few courts, that accords with public policy and current conceptions of res judicata and due process of law.

\section{RES JUDICATA}

A finding of corporate hability in a suit against the corporation alone has traditionally not been considered to inerge the plaintiff's entire cause of action into the judginent. ${ }^{9}$ Thus, the plaintiff may bring a subsequent suit against the owner, claiming that he should be held individually liable for the corporate obligation. ${ }^{10}$ Alternatively, in California a plaintiff may, after final judginent, obtain a hearing to show cause in order to establish the owner's individual hability. ${ }^{11}$ Under this procedure the plaintiff obtains a court order adding the owner's name as a judginent debtor. ${ }^{12}$

Unfortunately, courts have not analyzed the nature of the second suit, nor why it should be allowed. ${ }^{13}$ Instead, they have generally proceeded with the second suit, thereby effectively deciding that the plaintiff's cause of action against the owner has not been merged into the initial judgment. ${ }^{14}$ Despite the lack of critical analysis, both analogy

9. E.g., Minton v. Cavaney, 56 Cal. 2d 576, 364 P.2d 473, 15 Cal. Rptr. 641 (1961).

10. Id.

11. E.g., Thomson v. L.C. Roney \& Co., 112 Cal. App. 2d 420, 246 P.2d 1017 (2d Dist. 1952).

12. The order is issued pursuant to $\S 187$ of the California Code of Civil Procedure, which provides:

When jurisdiction is, by the Constitution or this Code, or by any other statute, conferred on a Court or judicial officer, all the means necessary to carry it into effect are also given; and in the exercise of this jurisdiction, if the course of proceeding be not specifically pointed out by this Code or the statute, any suitable process or inode of proceeding may be adopted which may appear most conformable to the spirit of this Code.

CAL. Civ. Proc. CODE $\$ 187$ (West 1954). The section is anbiguous and does not give much clue as to the theory behind its use.

13. For exainple, in Minton v. Cavaney the court dismissed defendant's claim of merger without discussion, unerely giving a citation to a partnership case. $56 \mathrm{Cal} .2 \mathrm{~d}$ at 581,364 P.2d at 478, 15 Cal. Rptr. at 644. See note 20 infra.

14. Perhaps the reticence of the courts to examine the question of whether a second suit should be permitted is based in part on the vagueness of the piercing theory itself. Commentators, for their part, have universally bemoaned the vagueness of piercing theory. See, e.g., Schifferman, supra note 4, at 785-86, 807; LATTIN, supra note 1 , $\$ 15$. The absence of analysis might also be caused by failure of defendants to plead res judicata as a defense to the plaintiffs claim. Res judicata must be pleaded by the parties; it will not be raised by the court even if the defense 
to other areas of the law in which a second action is permitted and an examination of the theory and policy considerations underlying res judicata in light of the circumstances surroundmg piercing support allowmg the plaintiff to maintain the action agamst the shareholder.

When the alter-ego doctrine is the theory behind piercing the corporate veil, allowing a second suit can be justified as a means of effectuating the first judgment. The premise of the alter-ego theory is that the plaintiff has shown that the corporation should not be treated as a separate entity at all, but that in practice the corporation is the mdividual. ${ }^{15}$ Thus the second suit is analogous'to a suit to enforce the original judgment against the corporation qua individual. ${ }^{16}$ California's statutory procedure, in fact, has been described as a way of adding the "real" name of the judgment debtor to the original judgment. ${ }^{17}$

When used agamst multiple owners, the alter-ego theory can be seen as treating the corporation as a partnership. ${ }^{18}$ The first suit, then, is analogous to a suit against a partnership im its common name to establish partnership liability. ${ }^{19}$ A second suit agamst corporate owners should thus be permitted, as it is in the partnership context, to establish

clearly exists. E.g., IB MOORE, supra note $8, \uparrow 0.405$ [1], at 629; RESTATEMENT OF JUDGMENTS $§$ 1, Comment a (1942) [hereinafter cited as Restatement]; FeD. R. CIV. P. 8(c).

15. See Latrin, supra note $1, \S \S 14,18$. Lattin suggests that the idea of alter ego and "identity" of parties inay be misleading. What is really going on is an application of agency law. The individual, as undisclosed principal, has used the corporation as an agent to further her own business. She is held liable as an individual under the doctrine of respondeat superior. Walkovszky v. Carlton, 18 N.Y.2d 414, 223 N.E.2d 6 (N.Y. 1966). Unfortunately, this theory does not fully explain why courts have insisted on "such unity . . that the separate personalities of the corporation and the individual no longer exist. . . " Automotriz del Golfo de Cal. S.A. de C.V. v. Resnick, 47 Cal. 2d 792, 796, 306 P.2d 1, 3 (1957). This fornulation contemplates a showing beyond a mere principal-agent relationship. Otherwise a separate piercing doctrine would not be necessary, and agency law would supply the governing standards.

16. See Restatement, supra note $14, \S 47(b)$. Cf. CAl. Civ. Proc. Code $\S 685$ (West Supp. 1978) (renewal judgmeut used to carry into execution an original judgment when 10 years lave passed front the date of its entry). Soine states permit an action between the same parties on the original judgment only under very restricted circumstances. E.g., N.Y. CIV. PRAC. LAW § 5014 (McKinney Supp. 1978). It inust be recognized that these sections are cited only by way of analogy. The second suit in a piercing coutext is not truly brought as an action on the first judgment. The owner is at least nouninally a party different from the corporation, although the second suit claims they are in practice the same. In this case, the law should vindicate the expectations of the plaintiff. See text accoinpanying notes 30-32 infra.

17. Thounson v. L.C. Roney \& Co., 112 Cal. App. 2d 420, 425, 246 P.2d 1017, 1020 (2d Dist. 1952).

18. See, e.g., Hiehle v. Torrance Millworks, Inc., 126 Cal. App. 2d 624, 272 P.2d 780 (2d Dist. 1954). Partners, of course, are not shielded from liability for debts and obligations of the partnership. E.g., Mason v. Eldred, 73 U.S. (6 Wall.) 231 (1867); Partnership Res Judicata, supra note 8 , at 863 .

19. At common law, a "partnership" could not be sued; suit could only be brought against the partners as individuals. Partnership Res Judicata, supra note 8, at 864. Common name statutes, e.g., CAL. CIv. PRoc. CoDE $\S 388$ (West 1973), recognize the partnership as an entity for procedural purposes and allow a plaintiff to sue the partnership in its common name. Partnership Res Judicata, supra note 8, at 871-72. 
the owners' individual liabilities for the corporation qua partnership's judgment debt. ${ }^{20}$

Allowing a second suit can also be explained under the undercapitalization approach. Piercing the corporate veil through undercapitalization in essence drops the shield agamst individual liability from the stockholder, while still recognizing the separateness of the corporate entity. Under this theory, a stockholder is held individually liable for having directly taken part, through participation in corporate affairs, in the act that gave rise to corporate liability. The stockholder's status is, therefore, that of a jomt obligor with the corporation. ${ }^{21}$ Under the inodern theory of joint obligations, judgment against one joint obligor does not extinguish the plaintiff's cause of action against other joint debtors. ${ }^{22}$ The existence of California's parallel statutory procedure for enforcing judgments against owners of a debtor corporation is consistent with the joint-obligor analogy, smce elsewhere California has explicitly provided a similar procedure in order to bind unserved joint obligors to a judgment. ${ }^{23}$

An even more compelling argument for permitting a second suit is that the individual owner-defendant is at least nominally a different legal entity from the corporation. An undercapitalization pierce does not attack the assumption that stockholder and corporation are separate entities. ${ }^{24}$ Even an alter-ego pierce claims only that the owner and corporation are the same im practice, not im theory. ${ }^{25}$ The second suit,

20. Partnership Res Judicata, supra note 8 , at 872 . The theory is suggested by the California Supreme Court in Minton v. Cavaney, 56 Cal. 2d 576, 581, 364 P.2d 473, 476, 15 Cal. Rptr. 641, 644 (1961). There the court cited Dillard v. McKnight, 34 Cal. 2d 209, 209 P.2d 381 (1949), a partnership case, in denying that res judicata prevented plaintiff from bringing the second suit.

21. See United States Envelope Co. v. Transo Paper Co., 221 F. 79 (D. Conn. 1915); Saxlehner v. Eisner, 140 F. 938 (S.D.N.Y. 1905), affd, 147 F. 188 (2d Cir.), cert. denied, 203 U.S. 591 (1906). In these two cases, officers of original corporate defendants were held liable with the corporation as joint infringers of a patent and a trademark, respectively. The joint-obligor analysis is only suggested by these cases, which were infringement rather than creditors' suits.

22. Restatement (SeCond) of Judgments $\S 94$ (Tent. Draft No. 3, 1976); Parmership Res Judicata, supra note 8, at 871.

23. Cal. Crv. Proc. Code $\S 989$ (West Supp. 1978); Partnership Res Judicata, supra note 8 , at 871 . The California statute provides in pertinent part:

When a judginent is recovered agamst one or more of several persons, jointly indebted upon an obligation . . . those who were not originally served with a summons, and did not appear in the action, may be summoned to appear before the court in which such judgment is entered to show cause why they should not be bound by the judgment

....

24. See text accompanying notes 21-23 supra.

25. Thus it is not inconsistent to claiun separate entities in the merger case while claiming the entities are the same for purposes of collateral estoppel. See notes 47-50 and accompanying text infra. The inerger question focuses on the plamtiff; the defendant asks whether the plaintiff should have brought the claim in the first suit. The collateral estoppel question focuses on the defendant; the plaintiff asks whether the defendant had suffieient control of the prior suit to be bound by issues litigated in that suit. 
therefore, is proper since it is against a different party. ${ }^{26}$

At first blush, the policies behind res judicata may appear to point toward not allowing the plaintiff to inaintain a second suit. The public policy of puttimg an end to litigation is against the plaintiff. ${ }^{27}$ The plaintiff has been given a day in court and, though successful, would normally not be allowed to bring a second action for further relief. ${ }^{28}$ Moreover, the doctrine of res judicata is intended to protect the parties froin the vexation and expense of repetitive litigation. ${ }^{29}$ A plaintiff who obtained a judgment against the corporation in the first action and who then unclertakes an alter-ego pierce, alleging that the corporation is in reahity the owner, has in effect brought a second suit on the saine cause of acticn against the same party. Even if it is ultimately determined that the corporation is not the owner's alter ego, the owner will have been put to the time and expense of defending a second lawsuit, after having paid for defense of the first suit indirectly through the corporation as a shareholder.

On further examination, however, these initial negative considerations are overcome. It is unlikely that the plaintiff deliberately chose not to name the corporate owner as a defendant in the first action in order to preserve another target should the initial action agamst the corporation be unsuccessful. Norinally, the plaintiff reasonably expects at the time of the first suit that the owner will not be individually liable for the corporation's debts and that the corporation will be financially able to pay them. ${ }^{30}$ It is, therefore, entirely reasonable not to join the owner as a party to the first suit. Furthermore, the entire foundation of the piercing theory is based on fairness to corporate creditors in the face of abuse of the corporate privilege by the owner. ${ }^{31}$ It would be anomalous to give the protection of res judicata to an owner who has so successfully hidden either her control of the corporation or

26. Of course, inerger also extinguishes a cause of action against privies of the parties to the original action even though they are "different" parties. See note 8 supra. An owner or stockholder has never been considered to be in privity with the corporation for inerger purposes. But cf. Dudley v. Smith, 504 F.2d 979 (5th Cir. 1974) ("A stockholder may be in privity with his corporation . . . if the two are found to be alter egos."). Furthermore, the modern view is to consider the fairness of applying res judicata in a particular case, rather than concentrating on formahisms like privity. See Parinership Res Judicata, supra note 8, at 884 n.10.

27. RESTATEMENT, supra note 14, \& 1, Comment a; lB MOORE, supra note $8, \uparrow 0.405$ [1], at 628; Polasky, Collateral Estoppel-Effects of Prior Litigation, 39 IowA L. Rev. 217, 219 (1954).

28. RESTATEMENT, supra note $14, \S 1$, Comment b.

29. 1B MOORE, supra note 8, I0.441 [1]-[2]; Developments in the Law-Res Judicata, 65 HARV. L. REV. 818, 820 (1952).

30. This characteristic distinguishes the corporate case from a partnership case where a plaintiff should expect the partners to be individually liable. The law should then encourage him to join as inany partners as possible in the first suit. Partnership Res Judicata, supra note 8, at 876.

31. The second part of the piercing test requires that "adherence to the [corporate] fiction .. . would, under the particular circumstances, sanction a fraud or promote imjustice." Minifiev. Rowley, 187 Cal. 481, 487, 202 P. 673, 676 (1921). See note 3 supra. 
a lack of corporate assets that the plaintiff does not discover the need to pierce the corporate veil until after the first action is concluded. ${ }^{32}$ Under such circumstances, it is clear that the plaintiff does not sue to gain further relief, but merely to receive the relief granted in the first suit.

The foregoing analysis confirms that despite the absence of judicial analysis on the question of whether the plamtiff's second action against the owner or stockholder is barred by res judicata, the general policy of permitting such suits is correct.

II

\section{Collateral EstopPel}

\section{A. The Present Rule}

While most courts have bypassed analysis of the res judicata issue, they have often discussed whether the plaintiff must relitigate the issue of corporate liability already determined in the previous suit. Most courts have leld that relitigation is necessary; the owner cannot be collaterally estopped in the second suit by a finding of corporate liability in the first suit. ${ }^{33}$ In accordance witl the usual principles of collateral estoppel, ${ }^{34}$ the only exception to the rule requiring relitigation arises when the plaintiff can show that the owner directly controlled the prior litigation. ${ }^{35}$ Then the owner will be bound by issues determined in the previous suit. ${ }^{36}$

The overt control exception is unnecessarily narrow and can lead to inequitable results. The stockholder of an undercapitalized corporation has already forced the plaimtiff to bring two lawsuits by successfully concealing the corporation's lack of assets. Even in an alter-ego

32. See Thomson v. L.C. Roney \& Co., 112 Cal. App. 2d 420, 426-27, 246 P.2d 1017, 1021 (2d Dist. 1952). This analysis assumes the plaintiff will be limited to the amount of liability found in the first suit. See text accompanying notes 70-73 infra. Normally the plaintiff would not have any other incentive to manufacture two suits, since it will also cost him time and money to litigate further. See note 72 infra.

33. E.g., Minton v. Cavaney, 56 Cal. 2d 576, 364 P.2d 473, 15 Cal. Rptr. 641 (1961). Contra, Dudley v. Smith, 504 F.2d 979 (5th Cir. 1974).

34. The party to be bound must generally have a sufficient interest in the suit as well as control over the litigation. E.g., 1B MOORE, supra note 8, \$ 0.411, at 1253; RESTATEMENT (SECOND) OF JUdGMENTS $\S 83$ (Tent. Draft No. 2, 1975); RESTATEMENT, supra note 14, § 84. The interest requirement is easily met by the owner's financial imterest in the corporation.

35. E.g., Ark-Tenn Distrib. Corp. v. Breidt, 209 F.2d 359 (3d Cir. 1954).

36. The overt control condition has also been a prerequisite for invoking California's statutory procedure to bind an owner individually for the corporate judgment debt. Compare Tliomson v. L.C. Roney \& Co., 112 Cal. App. 2d 420, 246 P.2d 1017 (2d Dist. 1952) and Mirabito v. San Francisco Dairy Co., 8 Cal. App. 2d 54, 47 P.2d 530 (1st Dist. 1935) (parent corporations in control of prior hitigation against subsidiaries bound) with Minton v. Cavaney, 56 Cal. 2d 576, 364 P.2d 473, 15 Cal. Rptr. 641 (1961) (defendant not bound though he filed an answer as corporate attorney, because he withdrew before the first trial and did not participate further). 
context the plaintiff has been forced to bring two suits because the corporation, although adequately capitalized, has been unable to fully satisfy its obligation. ${ }^{37}$ The restrictiveness of the overt control exception compounds this injustice. An owner or stockholder can force the plaintiff to the further delay and expense of relitigating corporate liability merely by avoiding active participation in the first suit or by participating so covertly that the plaintiff will be unable to prove control of the earlier litigation.

The likelihood of an owner disguising control of the earlier defense is great since the owner has nothing to lose ${ }^{38}$ and everything to gain by such a strategy. A plaintiff who loses the first suit will lose the claim and will probably be barred froun rehtigatimg the matter. ${ }^{39}$ If the plaintiff wins, the owner still has the opportumity to relitigate the issue of hability in the second suit, if it appears that the stakes are high enough and the chances of winning good enough to justify the costs of suit. The owner might even decide to fight what would normally be a margmal or losing battle, in hopes that the jury will be more sympathetic and find less or no hability since the defendant is now a real person rather than a corporation.

The prevailing rule requiring plaintiffs to rehitigate the issue of corporate liability unless overt control can be shown also does not accord with the usual policies behind the field of res judicata. The doctrine of collateral estoppel balances the public pohcies im favor of judicial economy, avoidance of imconsistent verdicts, and protection of hitigants froin unnecessary expense ${ }^{40}$ against the need for a full and fair hitigation of each issue. Even though a court allows a second suit, there is no reason to burden the plamtiff, or the court, unnecessarily with proving issues that have already been determined in the plaintiff's favor. ${ }^{41}$ In addition, the possibility of inconsistent outcomes that would result from a finding of no hability im the second suit has an adverse inpact on the stability of society and the judicial system, and

37. It is possible, of course, that the corporation's financial difficulties became acute after the first suit was completed, but before the plaintiff was able to execute the money judgment. Thus the necessity for the second suit would not be caused because the owner concealed a rocky financial base, but by subsequent events. But in such a case the owner herself would not expect a later pierce and would probably participate to the fullest in the first suit to protect her corporation's definite financial stake in the outcome. The plaintiff would then have no difficulty in binding the owner in a second suit by showing her actual participation and control in the first.

38. Except the owner loses the costs of the second suit, if the plaintiff brings it.

39. See note 8 supra.

40. See generally 1B MOORE, supra note 8, II 0.441 [1]-[2], 0.444 [1]; Vestal, Res Judicata/Preclusion: Expansion, 47 So. CAL. L. Rev. 357, 379 (1974); Developments in the Law-Res Judicata, 65 HARv. L. REV. 818, 820 (1952).

41. IB MOORE, supra note 8, I 0.405; Restatement, supra note 14, § 1, Comment a; Polasky, supra note 26, at 219-20; Note, Collateral Estoppel of Nonparties, 87 HARV. L. REV. 1485, 1501 (1974) [hereinafter cited as Nonparty Estoppel]. 
impairs the ability of individuals to plan future conduct. ${ }^{42}$

This analysis strongly supports the application of collateral estoppel to the issue of corporate liability in a suit against the owner. Normally corporate liability will be fully and fairly hitigated in the initial suit. ${ }^{43}$ Therefore, it is fair to bind the owner of the corporation as to this issue in the second suit. The current rule requiring rehitigation of corporate liability, however, relies on the fact that the owner as an individual is not inade a party to the original suit against the corporation. ${ }^{44}$ In the absence of control of the litigation, due process of law and other values important to our judicial systein nornally prevent collateral estoppel froin operating against a nonparty to prior litigation. ${ }^{45}$ Yet a corporation is a mere legal construct; it has no ability to appear in court or present a defense. The persons in control of the corporation engage in these acts on behalf of the corporation, and control of the corporation is precisely the issue with which piercing the veil is concerned in alter-ego cases. ${ }^{46}$ The only issue that needs to be determined in the

42. Polasky, supra note 26, at 219-20; Nonparty Estoppel, supra note 41, at 1501 .

43. Default judgments present a special problem because of the requirement that questions that are conclusive must have been actually litigated and determined in the previous action. See note 8 supra. At least one court has said that to hold an owner bound to a default judgment against his corporation would be a violation of due process of law. Motores de Mexicali, S.A.v. Superior Court, 51 Cal. 2d 172, 331 P. 2d 1 (1958). It might be argued that the sole-owner/alterego of a corporation, who has already had a chance to litigate the corporate liability and has declined to do so, should not be allowed to complain later when served as an individual. Yet it is perfectly reasonable for the owner not to litigate when the minimal assets of the corporation do not justify the costs of suit, especially since she cannot be sure she will later be defending her personal assets.

The circumstances become more complicated when the alter ego is more than one person, and all controlling owners have participated in, but not agreed with, the decision to default. When the corporation has undertaken to litigate, the court can at least presume that the owner's interests have been represented in decisions affecting the litigation, and that the corporation as a whole fully and fairly defended against liability. See RESTATEMENT (SECOND) OF JUDOMENTS § 83 (Tent. Draft No. 2, 1975); Restatement, supra note 14, \& 84, Comment e (shared control). But when judgment has been entered by default, the court cannot rely on an otherwise fair litigation of the issue of liability, since there was none. It would be both difficult and inappropriate for the court to attempt to determine whether a particular owner agreed with the decision. In both the single and multiple owner situations the defendant is attempting an initial litigation of the liability issue, not a relitigation. Thus the res judicata policies against forcing a plamtiff to prove an issue already determined in his favor and agamst the possibility of inconsistent determinations are not involved. Therefore, in accordance with the "actually litigated" requirement, default judgments should not be held concIusive as to the issue of corporate liability.

44. E.g., Minton v. Cavaney, 56 Cal. 2d 576, 581, 364 P.2d 473, 476, 15 Cal. Rptr. 641, 64445 (I961).

45. Motores de Mexicali, S.A. v. Superior Court, 51 Cal. 2d 172, 331 P.2d 1 (1958); Nonparty Estoppel, supra note 41, at 1496-97. But see note 46 infra.

46. Even the traditional aversion to nonparty estoppel has diminished somewhat in recent years. See, e.g., Gerrard v. Larsen, 517 F.2d 1127 (8th Cir. 1975); Cauefield v. Fidelity \& Casualty Co., 378 F.2d 876 (5th Cir.), cert. denied, 389-U.S. 1009 (1967); Roode v Michaelian, 373 F. Supp. 53 (S.D.N.Y. 1974). Nonparty estoppel lias been analogized to class actions, in which an absent meinber of the class can be bound by an adjudication in whicl the member did not person- 
second suit is, therefore, whether the corporate veil should be pierced to hold the owner individually hable for the obligation.

\section{B. A New Rule of Presumption of Control}

When the court forces a plaintiff to prove the owner's overt control of the prior litigation in order to avoid rehtigation of the issue of corporate hability, it shifts the focus away from the key issue. The plaintiff, by successfully piercing the veil under an alter-ego theory in effect has proven that the corporation is inseparable from the owner. The corporation's hability is attributed to the owner not only because of personal control over the corporation, but because its acts are the owner's acts, its interests are the owner's interests. ${ }^{47}$ Thus the owner must have controlled the prior hitigation and represented any personal interests fully in the process. ${ }^{48}$ As one court asked, "Who else had authority to employ attorneys and provide for the expense? Who else was interested in the fate of the corporation?"49 The courts should therefore adopt a new rule that estabhshes a presumption of control of the previous hitigation, and the owner should be bound under the estabhshed doctrine of overt control. ${ }^{50}$

ally participate. Vestal, Res Judicata/Preclusion: Expansion, 47 So. CAL. L. REv. 357, 377-79 (1974).

47. See note 3 supra.

48. It appears to be an unsettled question whether, in order to establish individual liability, it is necessary that the owner was acting as the alter ego at the time the obligation was incurred, at the time of suit, or both. Schifferman, supra note 4, at 805-06. It is theoretically possible to hold a person individually liable if that person was the corporation's alter ego at the time the obligation was incurred, even though that is no longer true at the time of suit. See Meadows v. Emett \& Chandler, 99 Cal. App. 2d 496, 498, 222 P. 2d 145, 146 (lst Dist. 1950). Of course, if the individual was not the alter ego at the time of suit, the presumption of control cannot follow. The plaintiff inust then show actual control, or the owner should be allowed to relitigate. This situation probably arises rarely since there are seldom changes in ownership and control in one-person and closely-held corporations, which are most susceptible to alter-ego piercing.

49. Sehoenberg v. Romike Properties, 251 Cal. App. 2d 154, 168, 59 Cal. Rptr. 359, 369 (2d Dist. 1967).

50. See note 35 and accompanying text supra. The court in Schoenberg v. Romike Properties, 251 Cal. App. 2d 154, 59 Cal. Rptr. 359 (2d Dist. 1967) appeared to use just such an analysis, although the court's language can also be read to inean that the court applied only a rebuttable presumption of control. Id. at $168,59 \mathrm{Cal}$. Rptr. at 369 . One court reached the same result by holding that a corporation and a stockholder are in privity when they are found to be alter egos. Dudley v. Smith, 504 F.2d 979 (5th Cir. 1974). Unfortunately, the finding of privity, as is often the case, allowed the court to sidestep any true analysis of the appropriateness of applying collateral estoppel in the particular context. See Bruszewski v. United States, 181 F.2d 419, 423 (3d Cir.) (Goodrich, J., concurring), cert. denied, 340 U.S. 865 (1950); Partnership Res Judicata, supra note 8 , at 884 n.110.

The court in Sparks Nugget, Inc. v. Commissioner, 458 F.2d 631 (9th Cir. 1972), cert. denied, 410 U.S. 928 (1973) held individual taxpayers estopped on an issue determined in a previous tax suit against their wholly-owned corporation. That court also based its holding on a finding of privity, but it cited IB MOORE, supra note 8, 10.422 [3], which suggests that tax suits ought to be special cases. The analysis presented in this Comment is persuasive that no such distinction should be inade. 
It might be argued that a conclusive presumption of control of the litigation should not be made if the alter-ego pierce is against multiple owners; one owner could have left control of the litigation to his coowners. Nevertheless, in the multiple owner context, the pierce still means that each owner has joint control and interest in the corporation; the corporation is in effect a partnership. ${ }^{51}$ Since absent compelling circumstances partners should be bound to a finding of partnership liability, so should the corporate owners. ${ }^{52}$

Although the presumption of control of the first suit should be conclusive, if the court determines that compelling circumstances prevented a full and fair opportunity to litigate $\mathrm{m}$ the first suit, relitigation is nevertheless appropriate. ${ }^{53}$ For example, when the assets of the corporation as well as of the inajority of owners are minimal, a co-owner with substantial individual assets who wanted to put up a spirited defense might nevertheless be outvoted. ${ }^{54}$ If these circumstances prevented a full and fair opportunity to litigate in the first suit, then the court should allow relitigation. Permitting the traditional flexibility of collateral estoppel to operate in the corporate context is especially important also because no shareholder, even an affluent co-owner with voting control, will be able to make a fully informed choice whether to vigorously defend the corporate assets at stake in the first suit, as there is normally no expectation of individual liability at that time. ${ }^{55}$ Yet in order to allow the alter-ego pierce, the court must find not only unity of ownership between the corporation and the individual, but unity of $\mathrm{m}$ terest as well. ${ }^{56}$ Since this unity of interest must have been present for the alter-ego pierce, the co-owner would have expected to bear the burden of an adverse judgment through his interest in the corporation. If the assets of the corporation were substantial, even though they later

51. See text accompanying notes 18-20, supra.

52. Only in a minority of states are partners collaterally estopped by a finding of partnership liability where they were not joined as individuals or did not control the first suit against the partnership. The desirability of this rule is argued at length in Partnership Res Judicata, supra note 8 , at $877-85$.

53. Restatement (Second) of Judgments $\S \S 68.1$ (e)(iii) (Tent. Draft No. 4, 1977), 88 (Tent. Draft No. 3, 1976).

54. The owner may want to defend the suit to protect even minimal assets, to attempt to prevent bankruptcy, or to preserve the good will inhering in the corporation's or owner's good name. Decisions affecting the hitigation in a multiple defendant or shared control context, like partnership decisions, are made by a majority vote of the participants. Each participant still "controls" the litigation, just as each partner controls the partnership, through an equal vote in decisions, even though the individual participant may not have voted with the majority im making a particular decision. Compare Restatement, supra note $14, \S 84$, Comment e with UNIFORM PARTNERShIP ACT \& 18(e), (h).

55. The expectation factor at least partially distinguislies the corporate case from the partnership case, where a partner knows at the outset that individual liability will result from partnership obligations. See note 18 supra; Partnership Res Judicata, supra note 8, at 878.

56. See note 3 supra. 
proved insufficient to satisfy the judgment, it is likely that a full and fair opportunity to litigate took place in the attempt to protect the corporate assets. In that case it would be fair to bind all of the owners. ${ }^{57}$

The considerations leading to a conclusive presumption of litigation control with an alter-ego pierce do not necessarily apply if undercapitalization is the basis for piercing the corporate veil. To pierce the veil under these circumstances, the plaimtiff need only show that the stockholder actively participated in corporate affairs, not that she totally controlled them. ${ }^{58}$ Thus the inference that she controlled prior litigation is not as strong. In addition, it may not be until the second suit that the stockholder realizes the possibility that she may be held personally liable for the corporate obligation. If the stockholding is relatively small, the stockholder might not have been keenly interested in the outcome of the first suit agamst the corporation. This distinguishes such a stockholder from the alter-ego owner, who also has unity of interest with the corporation. Moreover, unlike an alter-ego owner, in protecting the interests of the corporation in the first suit the stockholder would not necessarily have been so protective of individual interests since her financial imterest was so small.

Nevertheless, if, as required by the piercing standard, the stockholder was an active participant in corporate affairs-norinally an officer or director-tlie law sliould raise a rebuttable presumption that she at least shared control of the litigation with the other officers and directors. Since the stockholder also has some financial mterest in the outcoine of the first suit, established doctrine dictates that she should be bound by a finding of corporate liability. ${ }^{59}$ The presumption of control should not be overcome by a showing that it was counsel for the corporation who actually conducted the prior litigation, ${ }^{60}$ since corporate counsel will be responsible to the officers and directors wlio guide the corporation. ${ }^{61}$

Where a showing is inade that the stockholder was not concerned with the day-to-day management of the corporation's business, however, even though she might have actively participated in corporate affairs (as a fornal director, for mstance), the presumption sliould be considered rebutted. It is inore likely that a nonmanaging director did not share active control of the corporate defense. As a nonmanager,

57. See Restatement (Second) of Judgments, Reporter's Note app. $\S 88$, at $170-74$ (Tent. Draft No. 3, 1976).

58. See notes $4 \& 5$ and accompanying text supra.

59. Restatement (Second) of Judgments $\$ 83$, Comment c (Tent. Draft No. 2, 1975); Restatement, supra note 14, $\$ 84$, Comment e. Contra, Minton v. Cavaney, 56 Cal. 2d 576, 364 P.2d 473, 15 Cal. Rptr. 641 (1961). See also the qualification at note 5 supra.

60. Restatement (Second) of Judgments \& 83, Comment c (Tent. Draft No. 2, 1975).

61. See, e.g., CAL. CORP. CODE $\$ \$ 300$ (a) and 1975 legislative committee comment (a), 312(a) (West 1977); Del. Code tit. 8, § 141(a) and comment (x). 
this stockholder is probably also less culpable than a manager for the act which gave rise to the lawsuit. The analogy of the nonmanager's status to that of a joint tortfeasor or defaulter on a corporate obligation is not as strong. ${ }^{62}$ In such a case it would be fair to allow relitigation of corporate hability before holding the stockholder personally liable. ${ }^{63}$

The presumption of control proposal, if adopted, should not violate the standards of due process of law. ${ }^{64}$ The United States Supreme Court has held that it is constitutional to bind even stockholders who do not participate in corporate affairs when their corporate rights, privileges, and liabilities are litigated in a suit against the corporation. ${ }^{65}$ It can be argued that this holding was based on an implied contract between the stockholder and the corporation that the stockholder's liability could be determined only for this limited purpose. ${ }^{66}$ The decision was no doubt based on considerations of expediency; all shareholders cannot be allowed to individually relitigate the corporate liability when only their limited liability through the corporation is at stake. The Court might not be willing to go so far in finding privity when an attempt is made to hold a nonparticipating stockholder personally liable for the entire corporate obligation. ${ }^{67}$

When the presumption of control of the prior litigation can be fairly made, however, the strictures of due process of law are satisfied,

62. See text accompanying note 21 supra. When a corporation controls the target corporation through an interlocking board of directors, the defense of no actual control should not be available. Although certain directors or officers may be different, the parent corporation as an entity still controls both the subsidiary and the prior litigation and, therefore, should be bound by a finding of corporate liability. See Thomson v. L.C. Roney \& Co., 112 Cal. App. 2d 420, 246 P.2d 1017 (2d Dist. 1952) (making the point in an alter-ego setting).

63. See Ark-Tenn Distrib. Corp. v. Breidt, 209 F.2d 359 (3d Cir. 1954). Of course, if the plaintiff can show actual control of the previous suit, the nonmanager would be estopped under existing principles. See text accompanymg notes 34-36 supra. If, on the other hand, the director did not have an ownership interest in the corporation, yet was still susceptible to a pierce, see note 5 supra, she should not be bound by the prior judgment. Under those circumstances the director would have been acting solely as a fiduciary representative of the corporation in the first suit and could not have been representing personal interests. See RESTATEMENT (SECOND) OF JUDGMENTS $\$ 80$ (Tent. Draft No. 2, 1975); RESTATEMENT, supra note $14, \S 80$.

64. See U.S. ConST. annend. XIV, $\$ 1$.

65. Selig v. Hamilton, 234 U.S. 652 (1914) (stockholders liable to amount of their stock holdings under Minnesota law; stockholders estopped on issue of corporate liability and amount of assessment determined in previous sequestration and assessment proceedings against corporation; constitutionality affirmed).

66. Cf. F.R. Patch Mfg. Co. v. Capeless, 79 Vt. 1, 11, 63 A. 938, 940 (1906) (unincorporated association).

67. But see Zenith Radio Corp. v. Hazeltine Research, Inc., 395 U.S. 100, 110-11 (1969). The limited usefulness of privity as a concept in res judicata law has long been recognized. See Partnership Res Judicata, supra note 8, at $884 \mathrm{n} .110$. Nevertheless, it is still used to justify binding someone who was not a party to prior litigation to issues determined in that suit. E.g., Dudley v. Sinith, 504 F.2d 979 (5th Cir. 1974). See note 8 supra. An explicit finding of privity should not be necessary, however, as long as the particular concerns of due process are satisfied. See text accoinpanying notes 68 \& 69 infra. 
even though a corporate owner or stockholder is prevented from relitigating the issue of corporate liability. In fact, the limits of due process are not approached simce the Court has ruled that even absent parties can be bound by a judgment so long as "the [state] procedure fairly insures the protection of [their] interests." 68 When an owner or managing stockholder shares control of the prior litigation, the due process concerns of adequate representation, notice, and opportunity to be heard are ipso facto satisfied. ${ }^{69}$

Finally, in the interest of fairness, the proposed presuinption-ofcontrol doctrine should be tempered by a judgment limitation. Since the plaintiff in a second piercing suit might not invoke collateral estoppel, ${ }^{70}$ the defendant owner or stockholder should be permitted to estop him on the extent of hability found in the first judginent. Absent such a limitation, there is a danger that plaintiffs seeking protection against an unusually low damage award in the initial suit against the corporation will deliberately pass up a possible piercing claim in order to preserve a future claim against individual owners. If the award in the first action is satisfactory, the plaintiff could simply utilize the alternative statutory procedure to bind the owner to the previous judgment. ${ }^{\text {II }}$ If the award is inadequate, the plamtiff could then initiate a second lawsuit in which he would not plead collateral estoppel, but would attempt to relitigate the issue of hability in hopes of obtaining a higher verdict.

Allowing the defendant to limit the judgment removes any incentive for the plaintiff to manufacture two lawsuits. ${ }^{72}$ Judicial economy

68. Hansberry v. Lee, 311 U.S. 32, 42 (1940).

69. See Mullane v. Central Hanover Bank \& Trust Co., 339 U.S. 306, 313-14 (1950); Hansberry v. Lee, 311 U.S. 32, 40, $42-43$ (1940). Cf. Partnership Res Judicata, supra note 8, at 884-85 (binding a non-party partner who has not participated in the prior litigation).

70. See note 14 supra.

71. In a proceeding to show cause the plaintiff is constrained by the pleaded claims and theories of the first action. Cooper v. Birch, 140 Cal. 548, 74 P. 37 (1903).

72. It is open to question how often a plaintiff would even consider such an incentive to manufacture two suits. It is possible, however, that the plaintiff is on unfriendly terms with the sole owner of a corporation or the family owners of a close corporation. The plaintiff might plan to bring an uneconomical second suit, knowing a piercing theory was viable in the first suit, as a means of harassment. If the defendants can show this is his purpose, the court should prevent him from relitigating.

It is also possible the plaintiff has sued a foreign corporation. While it may be easy to establish "minimum contacts" in order to get jurisdiction over the corporation, see international Shoe Co. v. Washington, 326 U.S. 310 (1945), the plaintiff nay have wished to avoid a lengthy battle if he tried to get jurisdiction over the owner or owners in the same suit. The failure to join the owners as individuals could also be caused by the madvertence or incompetence of counsel. Inadequate discovery, either because of counsel's inadequacy or because the amount of the suit did not justify it until judgment, may not have revealed the corporation's rocky financial base. In either case, the plaintiff should not be penalized. The res judicata analysis does not change despite the arguments relating to litigation justice; the second suit is still agamst a different party. The collateral estoppel analysis would also not change since control of the first suit is not affected by the reason for plaintiffs failure to accomplish joinder. Unless the defendant can prove inalice, it is unnecessary and inappropriate for the court to inquire into the reasons necessitating two suits. 
is encouraged by giving plaintiffs an incentive to litigate the first suit against the corporation to its fullest and to join owners as individuals if that appears necessary to ensure that a judgment can be collected. Judgment limitation will also enhance the image of stability and fairness in the judicial system by discouraging widely differing judgments on the amount of corporate liability. Finally, if the plaintiff chooses to relitigate the issue of corporate liability in the second action, judgment limitation gives the defendant the option of placing a cap on potential individual liability while still allowing her to argue for a lesser award if slie disagrees with plaintiff's assessment of the inadequacy of the original judgment. ${ }^{73}$

\section{CONCLUSION}

Under current law, litigants who seek money judgments against corporations receive markedly different treatment if the corporation is unable to pay an adverse judginent. When a potential litigant is unable to gain relief from the corporation because the owner or stockholder has abused the corporate privilege, courts have not hesitated to pierce the corporate veil to prevent injustice. Yet when a successful litigant is placed in the same position, most courts unthinkingly force the plaintiff to the burden of relitigation to vindicate the judgment.

Modern developments in res judicata and due process have focused attention on the competing policies that underlie the doctrines: judicial econoiny and fairness to the litigants. In the past courts have only allowed disappointed plaintiffs to bring a second lawsuit to hold stockholders and owners personally liable for corporate obligations and generally have refused plaintiffs' use of collateral estoppel. If the courts are to fully effectuate the policies behind res judicata, they should reexamine their unwillingness to apply the doctrine of collateral estoppel against a defendant unless the plaintiff can prove overt control of the prior litigation. Courts should perceive that when the doctrines of res judicata and veil piercing are exalnined together, the concerns limiting the use of collateral estoppel are satisfied when the conditions necessary to pierce the corporate veil are met. In such cases, therefore,

73. Plaintiff, of course, would not risk relitigating the issue of corporate liability by not pleading collateral estoppel unless he felt the original judginent was grossly inadequate. It is unlikely his and the defendant's evaluation would differ so greatly. Thus the defendant would exercise the option of judgment limitation in most cases. 
absent compelling circumstances, the courts should extend the additional benefits of collateral estoppel to the unsatisfied plaintiff. ${ }^{74}$

Glenn M. Gottlieb*

74. The effect upon other state interests of adopting the presumed control approach will probably be slight. Corporations' decisions as to the best state in which to incorporate should not be affected. With inodern discovery practices, an owner's abuse of the corporation should in most cases be discovered in time for the first suit. See FED. R. CIV. P. 26-37. The vast najority of small corporations, which will be inost susceptible to a piercing theory, will make their decision where to locate much as a partnership would. See Partnership Res Judicata, supra note 8, at 880 n.93. Many inore inportant concerns-state taxation, the flexibility of state corporation codes, busmess developinent costs-imfluence a corporation's decision where to incorporate inore than whether a finding of corporate liabihty in a suit against the corporation will be autonatically binding on its directors or owners in a suit to establish their personal liability. Their decisions as to the best state in which to do business, taking into account the ease with which a corporation can be subjected to the jurisdiction of a state's courts, see note 72 supra, should be similarly unaffected.

* A.B. 1975, University of Cahfornia, Santa Barbara; J.D. 1978, Boalt Hall School of Law, University of California, Berkeley. Meınber of the California Bar. 
. 